ECONOMICS

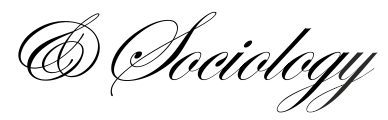

\author{
Sandeep Goyal, \\ Management Development Institute, \\ Haryana, India, \\ E-mails: sandy2u@gmail.com; \\ sandeep.goyal@competitiveness.in \\ Bruno S. Sergi, \\ University of Messina, Italy, \\ Davis Center for Russian and \\ Eurasian Studies, \\ Harvard University, \\ Cambridge, USA \\ E-mail:bsergi@fas.harvard.edu
}

\author{
Amit Kapoor, \\ Institute for Competitiveness, \\ Haryana, India, \\ E-mail: \\ amit.kapoor@competitiveness.in
}

Received: July, 2014

1st Revision: October, 2014

Accepted: November, 2014

DOI: $10.14254 / 2071-$

789X.2014/7-4/2

JEL Classification: L32
Goyal, S., Bruno, S. Sergi, Kapoor, A. (2014), Understanding the Key Characteristics of an Embedded Business Model for the Base of the Pyramid Markets, Economics and Sociology, Vol. 7, No 4, pp. 26-40. DOI: 10.14254/2071789X.2014/7-4/2

\section{UNDERSTANDING THE KEY CHARACTERISTICS OF AN EMBEDDED BUSINESS MODEL FOR THE BASE OF THE PYRAMID MARKETS}

\begin{abstract}
The objective of this article is to understand the significance and key characteristics of the socially embedded business model to achieve the socio-economic success at the base of the pyramid (BoP). The qualitative multi-case based analysis is applied for data collection and analysis. The sampling involves the field interaction with the four social enterprises targeting the energy and healthcare needs of the BoP segment in India. The findings involve conceptualizing the framework comprising the key focus areas and the underlying strategic actions required for an embedded business model across the BoP markets. The key focus areas include the focus on local capacity building, non-traditional partnerships and grass-root learning based ecosystem for business model innovation. The positive socio-economic impact of these focus areas require the understanding, evaluation and fitment of the corresponding strategic actions. The strategic actions linked to the local capacity building involve designing the social marketing campaigns, enabling the brick-n-mortar presence and engaging the local individuals for last-mile connectivity and reach. The strategic actions linked to the non-traditional partnerships involve collaborating with knowledge institutions, government institutions and social enterprises operating at the grassroot level. Finally, the key strategic actions linked to the grassroot learning ecosystem involve building the community level engagement, conducting field-pilots and prototyping.
\end{abstract}

Keywords: India, energy, healthcare, social embeddedness; embedded business model; base of the pyramid; social enterprises; BoP markets.

\title{
Introduction
}

There is a gradual shift in the orientation of the global enterprises towards the underserved needs of the low-income population living across the rural and semi-urban locations in the developing countries. Prahalad and Hart coined the term "Bottom of the Pyramid" in 1998 to represent this low-income, underserved segment. Since 2002, there has 
been an increasing interest in understanding the context and strategic approach for targeting this low income segment also referred to as "Bottom of the Pyramid" or Base of the Pyramid or "BoP" (Prahalad \& Hammond, 2002; Prahalad \& Hart, 2002).

The BoP segment represents approximately 4 billion people around the world that live in the developing and underdeveloped economies, earn less than \$8 (Year 2002 PPP levels) per day and lack access to the formal market setup for the fulfillment of the essential social needs like food, energy, water, sanitation, healthcare, transportation, education and housing (Hammond et al., 2007; Kapoor \& Goyal, 2013; Goyal et al., 2013).

Prahalad and Hammond (2002) have described the BoP segment as both an opportunity as well as a challenge for the for-profit social enterprises looking at this segment for economic gains. Considering the size and proportion of the BoP, this segment represents a huge socio-economic opportunity for the global entrepreneurs (Hammond et al., 2007). However, the huge economic potential at the BoP has not led to the entry of the large number of for-profit enterprises. This formal market based demand-supply gap is mainly attributed to the perceived market risks and uncertainty resulting from the three types of market imperfections - socio-economic profile of the customer, infrastructure challenges and market setup related challenges (Cohen \& Winn, 2007; IFMR, 2011). The socio-economic profile of the customers poses challenges in terms of the low income levels, irregular cash flows, lack of savings pattern, limited mobility patterns, low literacy levels and lack of access to the formal market setup. The infrastructure related challenges include lack of reliable network of electricity, water, roads, technology and transportation across the rural and semi-urban areas. The market oriented challenges include lack of government support and informal market dominance.

These BoP market constraints require the social enterprises to shift focus from transaction oriented business model to engagement oriented business model. This implies the need to innovate and implement the socially embedded business model driven by the long term socio-economic focus rather than short-term economic gains. Franks (1999) argues that the social enterprises need to focus on social embeddedness by creating an enabling environment (administrative, legal, social, economic, political and infrastructure) for the BoP stakeholders. The embedded organizational setup and culture will enhance the entrepreneurial activity among the communities and people's skill levels at the BoP, thereby reducing the dependence of the BoP segment on the informal setup as well as increasing the awareness, trust and acceptance towards the formal market setup promoted by the social enterprises.

This article conceptualizes the key focus areas and the strategic actions required for implementing the socially embedded business model at the BoP. The qualitative multi-case based technique is used for data collection and analysis. This qualitative and exploratory mode of research is found to be particularly useful for understanding the business models and strategies in the developing economies (Hoskisson et al., 2000). The conceptual findings are identified and recommended based upon the field interaction and analysis of the experience of the four social enterprises delivering energy and healthcare linked offerings to the BoP segment in India.

The next section focuses on the review of the existing research literature related to the principle of social embeddedness. After the literature review, we describe the research scope, design and methods for this study. This is followed by a discussion of the results derived from the with-in and cross-case analysis of the experiences of the social enterprises identified for this study. The research is concluded by depicting the theory, practice and policy level implications as well as recommending the potential areas of future research in this direction. 


\section{Social Embeddedness - Literature Review}

The literature review focuses on the mainstream research journals that reflect the interest in the themes related to the base of the pyramid, social enterprises and social embeddedness during the period 1990s - 2013. The approach has been kept simple to ensure that the quality and relevance of the research articles are not missed out by narrowing the focus on selective impact based journals. Those articles are selected for review, which have the matching abstract, or title or body to any of the keywords like social embeddedness, social inclusion and local engagement.

The review of the research literature highlights the significance of the focus on the principle of local embeddedness for addressing the BoP market challenges related to the lack of awareness, need for social acceptance, need for ensuring the availability and accessibility of the affordable value offerings addressing the real needs of the BoP segment (Prahalad \& Hammond, 2002). The key research areas evident from the review of the existing literature on social embeddedness involve defining the principle of social embeddedness and identifying the key focus areas required for social embeddedness orientation at the BoP.

Regarding definition, Miller (1996) relates embeddedness to the degree of influence evident from the social and institutional connections of the enterprises on their strategy. This reflects the significance of defining an indigenous business model for operating in the BoP markets. Hart (2005) extends this further by emphasizing on the fact that the indigenous business model should not be disruptive to the prevalent culture and lifestyle of the poor and should be rather built upon the wealth and capabilities of existing resources and alternatives.

The review of the academic literature highlights the key focus areas, which are recommended for creating an embedded business model at the BoP.

First, there is a need to focus on building the local capacity in terms of the human capital, organizational resources and social capital (Chaskin et al., 2001). The focus on local capacity building involves training and engaging the local individuals from the BoP segment for value creation and delivery. Murphy and Thomas (2003) highlight the resulting socioeconomic benefits of the local engagement for the BoP segment in terms of the improvement in the quality of life, increase in income levels, recognition of the individual worth and motivational aspect. Gibb and Adhikary (2000) argue that the psychological and cultural barriers between the enterprise and the BoP segment are lifted by focusing on the local skill building and engagement.

Second, there is a need to develop the localized value network comprising the collaborations and partnerships with the non-traditional actors like government institutions, philanthropic organizations, NGOs, community based organizations and other informal market players serving the BoP segment (Hart \& Sharma, 2004; Hart, 2005; Hart \& London, 2005). The focus on building non-traditional partnerships enable the social enterprises access to the social infrastructure and legitimacy thereby enhancing market trust and acceptance at the BoP (London \& Hart, 2004; Brugmann \& Prahalad, 2007; Dahan et al., 2010; London et al., 2010). Also, these partnerships enable the social enterprises in gaining the better understanding of the $\mathrm{BoP}$ context, reducing the transaction costs, enabling the last-mile connectivity and reach by leveraging the existing market channels and gaining social acceptance among the masses (Putnam, 1995; Prahalad, 2004).

Third, there is a need to create grassroot learning based ecosystem at the BoP comprising the community based network and ability to conduct field-based experimentation and innovation. This is necessary to identify, create and deliver solutions which address the real needs of the BoP segment. Espositio et al. (2012) argue that there is a need to setup the bottom-up learning mechanism to understand the real needs at the BoP. Simanis and Hart (2006) argue that deepening the community level engagement with the fringe stakeholders 
leads to value co-creation thereby enhancing the scope of social acceptance. Yunus (2010) emphasizes the need for similar grassroot learning based ecosystem, which involves setting up the double-loop learning mechanism resulting in innovations and value co-creation. Regarding experimentation capability, this is necessary to address the ambiguity and uncertainty of the dynamic BoP environment (Simanis \& Hart, 2006; Yunus et al., 2010). This requires the ability and capacity to conduct the low-cost probes and prototyping before making significant time, capital and resources commitments towards any value offerings at the BoP (Simanis and Hart, 2006). The learnings from the field based experimentations should be translated into the product, process and business model innovations thereby improving the capabilities and fitment to the BoP context (Hart \& Sharma, 2004; Andersen \& Markides, 2007).

\section{Research Design}

\subsection{Research Scope}

The scope of this research involves multi-case based study of the for-profit social enterprises targeting the energy and healthcare needs of the BoP segment in India. The choice of India holds relevance primarily because this developing country comprises a large proportion of the global population categorized as the BoP segment. As per the World Bank (2010), 32.7\% of the population in India earn below the international poverty line of US\$1.25 per day (2005 PPP) while 68.7\% earn less than US\$ 2 per day. The majority of the BoP population in India lives across the semi-urban and rural areas. This leads to accessibility and availability challenges for the social entrepreneurs trying to target the BoP market.

The choice of the social enterprises focusing on the energy and healthcare needs is driven by the following assumptions. First, these social needs are linked to the Millennium Development Goals (MDGs) having global focus and attention. The MDGs are defined by the United Nations in a resolution passed by the General Assembly in 2000. These comprise eight specific goals targeting the demand-supply gaps and inefficiencies pertaining to the human rights, income levels, health, education, energy, information and environmental issues (Seelos \& Mair, 2005). Second, the lack of affordable access to the clean energy and quality healthcare solutions has adversely impacted the capacity of the BoP individuals to improve their life-style and household income (Kalam \& Singh, 2011). Third, the BoP segment spends more than $15 \%$ of its income on meeting the energy and healthcare needs (Kalam \& Singh, 2011). This expense goes into the consumption of the kerosene oil for lighting and cooking as well as getting health treatment from untrained physicians.

\subsection{Research Methodology}

This research adopts a mix of deductive-inductive research logic for conceptualizing the key focus areas and strategic actions required for an embedded business model at the BoP. The deductive logic involves identifying the key focus areas regarding social embeddedness, which were evident in the research literature. These focus areas are used as the broad framework for the inductive stage of this research. The inductive logic involves the application of a largely interpretive epistemological stance on primary and secondary data to conceptualize the outcome. Miles (1979) recommends that the logic of deductive-inductive approach enables the researchers to conduct interviews and structure the field inputs in an informative manner during the qualitative research.

This research adopts the qualitative multi-case based research methodology, which involves theory building by case study based research approach. 
The case study methodology involves the use of one or more cases to create theoretical constructs, propositions, and/or mid-range theory from case based (with-in and cross) empirical evidence (Eisenhardt, 1989). A multi-organization case study design allows for an in-depth analysis across different contexts and enables researchers to better understand how and why outcomes occur (Miles \& Huberman, 1994). The tentative explanations found in a within-case analysis can be tested across other cases, enhancing reliability and validity of the conclusions drawn (Yin, 2009).

The case study approach holds greater relevance than the survey or experimental approaches in those situations, where there is a need to maintain a holistic perspective during data collection and analysis of the real-life events in the study (Yin, 2009). The case study approach leads to theory development by utilizing the in-depth insights of empirical phenomenon and its underlying context (Dubois \& Gadde, 2002). The multi-case based research approach is undertaken due to the following reasons. First, BoP context is a complex phenomenon in terms of the customer profile, non-traditional stakeholders, competitive dynamics and infrastructure availability. Second, the understanding of the strategic actions for social embeddedness at the BoP requires an interpretive paradigm to collect, understand and analysis the field-based inputs from the diverse stakeholders of the selected social enterprises. These actions are not evident from the experiments or survey based statistical analysis (Esposito et al., 2012; Eisenhardt, 1989).

\subsection{Data Collection and Analysis}

\subsubsection{Data Collection}

The data collection phase is a crucial link between the research objectives and findings. The key aspects of the case study based research design involve setting up the criteria for sampling and data collection (Yin, 2009). The data collection is preceded by the design of case study protocol and sampling criterion.

The design of case study protocol is the initial step in the data collection phase. The case study protocol documents the data collection instruments, approach for field-based inputs, case study layout and the different stakeholder types for each data collection technique. This is necessary to ensure the reliability of the research design (Yin, 2009). The design of case study protocol for this research focused on the two main categories of inputs during data collection phase. The first category involved understanding the key challenges, BoP context, BoP needs, competitive dynamics and key focus areas. The second category involved understanding the operationalization of the different focus areas in terms of practices and processes.

The sampling approach for this research involved the iterative selection of the forprofit social enterprises targeting the energy and healthcare needs of the BoP segment. The subsequent social enterprises were chosen based upon the recommendation of the ones being interviewed earlier. The failed social enterprises could not be identified due to the private limited setup of these enterprises as well as limited details available in the public domain. However, the iterative cases were chosen to replicate previous cases or extend emergent theory or map the findings across the enterprises targeting the different needs at the BoP (Eisenhardt, 1989). The sampling criteria involved selecting the social enterprises having the following attributes:

- Setup as a private limited company in India.

- Targeted the energy and healthcare needs of the BoP segment. 
- Segmentation involved low income segment earning less than USD 2 (2005 PPP levels) per day and living in the semi-urban and rural areas across India. This was equivalent to the monthly household income of INR $13500^{1}$.

- Mission having a social orientation.

The sampling details are shown in Table 1 below. The Appendix 1 provides a brief overview of these enterprises.

Table 1. Sampling (List of Social Enterprises)

\begin{tabular}{|c|c|c|c|c|}
\hline Ref & Company & Need Addressed & $\begin{array}{c}\text { Year of } \\
\text { Inception }\end{array}$ & Offerings \\
\hline SE \#1 & Selco & \multirow{2}{*}{$\begin{array}{l}\text { Lighting and } \\
\text { Cooking }\end{array}$} & 1995 & \multirow{2}{*}{$\begin{array}{l}\text { Solar energy solutions with door-step } \\
\text { support and financing }\end{array}$} \\
\hline SE \#2 & Boond & & 2010 & \\
\hline SE \#3 & $\begin{array}{l}\text { Narayana } \\
\text { Hrudavalava }\end{array}$ & \multirow{2}{*}{ Healthcare } & 2001 & Primary, secondary and tertiary care \\
\hline SE \#4 & E Health Point & & 2009 & Primary care and clean drinking water \\
\hline
\end{tabular}

The data collection for this research involved collecting inputs from the diverse primary and secondary sources. The secondary sources of data included the company website and information available in the public domain. This was followed by the primary data collection from multiple stakeholders including the senior management team, operations team (sales team, nurses), customers (village households, patients) and field partners (regional rural banks, suppliers). The sources of primary data collection included the field interviews, focus groups and field observations. This multi-level and multi-source data collection approach is necessary for ensuring the internal validity and construct validity (Yin, 2009).

\subsubsection{Data Analysis}

The analytical stage for this research involved undertaking the with-in case analysis, cross-case analysis and comparison with the extant literature in parallel to the iterative mode of data collection. The data in the case reports was conceptualized via the coding process. This process involved first level reduction of the data analytically by comparing the events/actions/interactions against each other for similarities / differences thereby leading to conceptual labeling (Corbin \& Strauss, 1990). The conceptually similar ones were grouped together to develop categories and sub-categories. The coded data was compared and contrasted in an exploratory manner using the partially ordered data display technique for data analysis and reduction (Miles \& Huberman, 1994). The findings were continually updated and refined during the iterative inputs emerging from the continuing field studies and ongoing comparison of the findings with the extant literature. The results of the analysis are discussed in the next section.

\section{Discussion and Findings}

The findings of this study involve presenting the narrative comprising the emergent themes and the underlying strategic actions required for an embedded business model across the BoP markets. The themes include the focus on local capacity building, non-traditional partnerships and grass-root learning based ecosystem for field experimentation and innovation.

\footnotetext{
${ }^{1}$ Average HH size $=5 ; \$ 2 * 5=H H$ Income of USD 10 per day $(2005$ Rates; 1 USD $=I N R 45)=I N R 450$ per day (INR 13500 per HH per month).
} 


\subsection{Thematic Analysis and Strategic Actions}

\subsubsection{Local Capacity Building}

The BoP market challenges pertaining to the lack of social awareness, minimal social acceptance and scarcity of skilled resources require the social enterprises to focus on strategic actions aimed at local capacity building. The strategic actions involve conducting the social marketing campaigns and skill-building programs for the local individuals and institutions; ensuring the local presence by setting up the regional service and support centers across the rural and semi-urban locations; and engaging the local individuals across the organization as employees and micro-entrepreneurs.

Regarding the social enterprises providing energy solutions (SE\#1 and SE\#2), the first strategic action involved conducting the skill-building and awareness oriented training programmes for the local individuals and institutions. The second action involved setting up the brick-n-mortar centers thereby ensuring the last-mile presence. These sales and support setups were staffed by the local hires and carried high transaction costs but enabled the energy enterprises to maintain quality, develop trust with the locals and generate deep connections with the local community. The third action involved training and engaging the local individuals as micro-entrepreneurs, sales and support agents thereby enabling the inclusive set-up for last mile connectivity and reach.

The energy entrepreneurs (SE\#1 and SE\#2) highlighted the theme of local capacity building in the following comments:

"...holding demonstrations at public places as well as at homes...adopt business agents model, who act solo between the branches...training the local people as technical support staff and micro-entrepreneurs ...train these people (mainly local individuals) and they are as good as single person branch...rely on the brick-n-mortar setup engaging locals trained as technicians and support staff"'.

Regarding the social enterprises providing healthcare solutions (SE\#3 and SE\#4), the first strategic action involved undertaking the rural health camps and local awareness sessions to educate the local individuals regarding the ways and means of preventive and curative healthcare. The second action involved setting up the cluster based network of local hospitals, conducting rural health camps, forming partnerships with the local healthcare providers, and setting up hub-n-spoke network for last mile connectivity and reach. The third action involved training and engaging the local girls and women as nurses and paramedical staff members thereby enabling the inclusive set-up for last mile connectivity and reach.

The healthcare entrepreneurs (SE\#3 and SE\#4) highlighted the theme of local capacity building in the following comments:

"...conducting rural health camps and social marketing campaigns to create awareness on preventive and timely healthcare...encourage girls from poor households to get trained as nurses and engage them as the paramedical staff...use of telemedicine via satellite link to connect with patients in the remote villages...some of the staff has to be local, so that they understand the local context, sensitivity and communicate effectively with the local people..."

Proposition 1a. Social Enterprises make positive socio-economic impact by conducting social marketing campaigns for creating awareness and skill-building programs for the BoP segment.

Proposition 1b. Social Enterprises make positive socio-economic impact by focusing on brick-n-mortar setups thereby extending the last-mile connectivity and reach.

Proposition 1c. Social Enterprises make positive socio-economic impact by engaging the BoP individuals across the value-chain for value creation and delivery. 


\subsubsection{Non-Traditional Collaborations and Partnerships}

The BoP market challenges pertaining to the socio-economic profile (low income levels, irregular cash flows, low literacy levels, social pressure and large households) of the customer segment, lack of sufficient infrastructure and non-availability of skilled resources require the social enterprises to focus on strategic actions aimed at creating a value network comprising non-traditional collaborations and partnerships. The social enterprises focus on collaborations with diverse institutions like technology organizations, academic organizations, community based organizations (CBOs), government institutions, non-government organizations (NGOs), philanthropic organizations, other social organizations and informal market entities. These non-traditional partnerships enable the social enterprises to leverage the existing technologies for creating affordable value offerings and leverage the existing delivery network for gaining social acceptance as well as last-mile connectivity and reach.

Regarding energy enterprises (SE\#1 and SE\#2), the first strategic action involved collaborating with the technology and academic institutions. This enabled access to the technology and know-how for creating affordable solutions meeting the real needs of the BoP segment. The second action involved leveraging the infrastructure set-up and pro-poor policies of the government for extending the last-mile reach, creating social acceptance and bringing subsidy benefits to the poor. The third action involved extending the last-mile reach, social awareness campaigns and social acceptance by collaborating with the local institutions including NGOs, CBOs, philanthropic organizations, social enterprises and informal market entities.

The energy entrepreneurs (SE\#1 and SE\#2) highlighted the theme of non-traditional partnerships in the following comments:

"...global academic, technology and development institutions for designing new product and services offerings to the real energy needs of the poor...align with government to contribute in policy making...engage energy entrepreneurs...partnerships with regional rural banks for financing and awareness building...collaborations with NGOs for lastmile awareness, reach and trainings of the locals".

Regarding healthcare enterprises (SE\#3 and SE\#4), the first strategic action involved collaborating with the technology, academic and development institutions. These collaborations enabled access to the global technologies as well as clinical and non-clinical protocols for delivering the affordable quality healthcare to the BoP segment. The second action involved leveraging the existing rural network and government subsidies for enabling affordable access to healthcare for the extreme poor BoP segment living across the remote locations. The third action involved extending the last-mile reach, social marketing campaigns and social acceptance by collaborating with the local institutions including NGOs, CBOs, philanthropic organizations, social enterprises and informal market entities.

The healthcare entrepreneurs (SE\#3 and SE\#4) highlighted the theme of nontraditional partnerships in the following comments:

"...with technology and academic institutions to implement best processes, standards and software for tele-healthcare...collaboration with government institutions for choosing locations, to launch tele-medicine services, to connect remote villages and to build trust with local community...collaboration with NGOs has helped in terms of designing community engagement strategies, conducting rural health camps...offer incentive based referral scheme to rural medical practitioners".

Proposition 2a. Social Enterprises make positive socio-economic impact by collaborating with the academic, technology and development institutions.

Proposition 2b. Social Enterprises make positive socio-economic impact by collaborating with the government institutions. 
Proposition 2c. Social Enterprises make positive socio-economic impact by collaborating with the NGOs, CBOs, philanthropic organizations, social enterprises and informal market entities.

\subsubsection{Developing Grassroot Learning Ecosystem}

The BoP market is characterized by the dynamic environment in terms of the socioeconomic profile of the customers, infrastructure challenges, scarcity of skilled resources, scarcity of market data and informal market setup. These characteristics of the BoP market require the social enterprises to build capacity in terms of the grassroot learning based ecosystem. The strategic actions involve creating the community level engagement leading to value co-creation as well as enhancing the experimentation and innovation capacity by undertaking the low-cost probes and prototyping.

Regarding energy enterprises (SE\#1 and SE\#2), the first strategic action involved conducting live demonstrations of the solar products at public congregation places as well as promoting the community level engagements of the sales and support team by ensuring the participation in local festivals and events. The second action involved conducting the ongoing field pilots and prototyping for the different energy offerings at the BoP. These actions enabled the understanding of the real needs regarding energy offerings of the BoP segment.

"...field driven... local team at each of these centres gets involved in cultural festivals of

these people; become a community leader; understand their issues and provide solutions and thereby get locally embedded in the local society...community level engagement keeps us aware about different kind of needs and demands at the grassroot level and then we do the pilot with prototypes at those places, understand the customization needs, if any need be done and price points and then launch the same...engagement at the field level, helps us in learning about their real needs and willingness for different products".

Regarding healthcare enterprises (SE\#3 and SE\#4), the first strategic action involved training and engaging the local girls as nurses and customer support representatives thereby creating the local feel, trust and acceptance among the BoP customers visiting the hospitals. The second action involved conducting trial offerings for different healthcare products and services at different locations thereby evaluating the demand and acceptance before having a full-scale launch.

"...whatever area, we operate, we start involving the local community, in whatever ways, we can... a lot of competency actually gets built up locally by training the doctors of government healthcare centres in remote areas...listen to them carefully, when they visit you, you will get an insight into their needs... carry out multiple experiments and innovations. That helps to improve market learning as well as understanding... piloting maternal; /child care and chronic disease management services, in preparation for scaling the health business".

Proposition 3a. Social Enterprises make positive socio-economic impact by focusing on community level embeddedness and engagement.

Proposition 3b. Social Enterprises make positive socio-economic impact by focusing on fieldbased experimentations and grassroot innovations.

\subsection{Conceptual Framework}

The thematic analysis of the data collected from the primary and secondary sources confirms the significance of the local capacity building, non-traditional partnerships and grassroot learning based ecosystem in setting up an embedded business model at the BoP (Figure 1). 


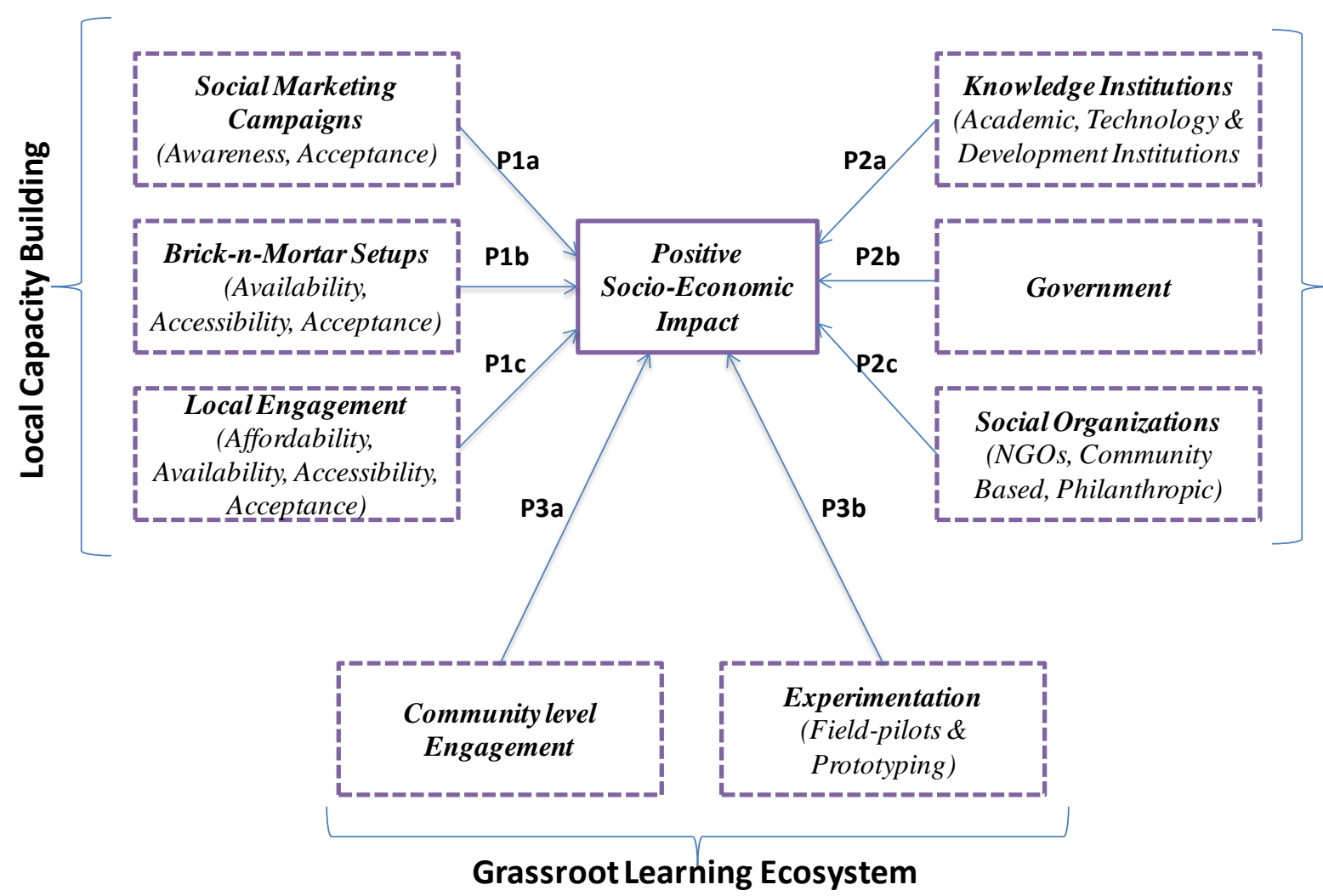

Figure 1. Conceptual Framework - Strategic Actions for Embedded Business Model

However, these focus areas need be understood in terms of the underlying strategic actions, which need be implemented for creating a positive socio-economic impact at the BoP. The strategic actions linked to the focus on local capacity building involve designing the social marketing campaigns, enabling the brick-n-mortar presence and engaging the local individuals for last-mile connectivity and reach. The strategic actions linked to the focus on non-traditional partnerships involve collaborations with knowledge institutions, government institutions and social organizations operating at the grassroot level. Finally, the strategic actions linked to the focus on grassroot learning ecosystem involve building the community level engagement, conducting field-pilots and prototyping.

\section{Implications for Theory, Management and Policy}

From the theoretical perspective, this article strengthens the existing belief that the focus on social embeddedness is necessary to tackle the challenges pertaining to affordability, accessibility, availability, awareness and acceptance at the BoP. The focus on social embeddedness requires the adoption of strategic actions aimed at creating an organizational culture, non-traditional social network and grassroot learning network.

From the management perspective, this article attempts to present a conceptual framework comprising the key focus areas and strategic actions, which will enable the social entrepreneurs to reduce the BoP market risks, uncertainty and make better informed decisions.

From the policy perspective, this article reflects the significant role of the government in the growth and entry of the social enterprises having socio-economic business model. This requires a shift in the orientation of the government at three levels. First, the government should provide the separate legal status to the social enterprises in congruence to their social mission as compared to the commercial or non-profit enterprises. Second, the government 
should create an ecosystem for incorporating the field-based recommendations of the active social enterprises while creating the policies as well as offering the benefits to the BoP segment. Third, the government should transform its role from implementation to facilitation. This implies enabling the social enterprises to align with and leverage the existing government network across the semi-urban and rural areas for social marketing, value creation and delivery.

\section{Conclusion}

This article highlights the significance of the social embeddedness principle in achieving the positive socio-economic impact among the rural dominated BoP markets. The focus on social embeddedness enables the social enterprises to address the BoP market challenges related to affordability, availability, accessibility, awareness and acceptance. The first contribution of this article lies in identifying the key focus areas aimed at building an embedded business model for the BoP markets. The second contribution of this article lies in identifying the key strategic choices linked to the key focus areas. These strategic choices need to be evaluated and implemented by the social entrepreneurs for ensuring effective socio-economic interventions at the BoP. However, there are limitations of this exploratory research in terms of the sample size and choice of social enterprises based focusing on energy and healthcare needs of the BoP segment in India. It is recommended to take this research further by expanding the scope in terms of the sample size and choice of locations and types of basic social needs being addressed. This will enable the progressive conceptualization of the social embeddedness framework presented in this article.

\section{Acknowledgement}

The authors would like to thank the Editor-in-chief, Prof. Tomasz Bernat and the anonymous referee for their helpful comments and suggestions.

\section{References}

Anderson, J., Markides, C. (2007), Strategic Innovation at the Base of the Economic Pyramid, MIT Sloan Management Review, Vol. 49, No. 1, pp. 83-88.

Brugmann, J., Prahalad, C. K. (2007), Cocreating Business's New Social Compact, Harvard Business Review, Vol. 85, No. 2, pp. 80-90.

Chaskin, R. J., Brown, P., Venkatesh, S., Vidal, A. (2001), Building Community Capacity, Aldine Transaction, New Brunswick, New Jersey.

Cohen, B., Winn, M. I. (2007), Market imperfections, opportunity and sustainable entrepreneurship, Journal of Business Venturing, Vol. 22, No. 1, pp. 29- 49.

Corbin, J., Strauss, A. (1990), Grounded Theory Research: Procedures, Canons, and Evaluative Criteria, Qualitative Sociology, Vol. 13, No. 1, pp. 3-21.

Dahan, N. M., Doh, J. P., Oetzel, J., Yaziji, M. (2010), Corporate-NGO Collaboration: Cocreating New Business Models for Developing Markets, Long Range Planning, Vol. 43, No. 2-3, pp. 326-342.

Dubois, A., Gadde, L. (2002), Systematic Combining: an Abductive Approach to Case Research, Journal of Business Research, Vol. 55, No. 7, pp. 553-560.

Eisenhardt, K. (1989), Building Theories from Case Study Research, The Academy of Management Review, Vol. 14, No. 4, pp. 532-550. 
Esposito, M., Kapoor, A., Goyal, S. (2012), Enabling Healthcare Services for the Rural and Semi-urban Segments in India: When Shared Value Meets the Bottom of the Pyramid, Corporate Governance, Vol. 12, No. 4, pp. 514-533.

Franks, T. (1999), Capacity Building and Institutional Development: Reflections on Water, Public Administrative Development, Vol. 19, No. 1, pp. 51-61.

Gibb, A., Adhikary, D. (2000), Strategies for Local and Regional NGO Development: Combining Sustainable Outcomes with Sustainable Organizations, Entrepreneurship and Regional Development, Vol. 12, No. 2, pp. 137-161.

Goyal, S., Esposito, M., Kapoor, A., Jaiswal, M.P., Sergi, B.S. (2014), Linking up: inclusive business models for access to energy solutions at base of the pyramid in India, Int. J. Business and Globalisation, Vol. 12, No. 4, pp. 413-438.

Hammond, A. L., Kramer, W. J., Katz, R. S., Tran, J. T., Walker, C. (2007), The Next 4 Billion: Market Size and Business Strategy at the Base of the Pyramid, Washington DC: World Resources Institute, http://www.wri.org/publication/the-next-4-billion (referred on $02 / 12 / 2014$ ).

Hart, S. L. (2005), Capitalism at the Crossroads: The Unlimited Business Opportunities in Solving the World's Most Difficult Problems, Wharton School Publishing, Upper Saddle River, New Jersey.

Hart, S. L., London, T. (2005), Developing Native Capability: What Multinational Corporations Can Learn from the Base of the Pyramid? Stanford Social Innovation Review, Vol. 3, No. 2, pp. 28-33.

Hart, S. L., Sharma, S. (2004), Engaging Fringe Stakeholders for Competitive Imagination, Academy of Management Executive, Vol. 18, No. 1, pp. 7-18.

Hoskisson, R. E., Eden, L., Lau, C. M., Wright, M. (2000), Strategy in Emerging Economies, Academy of Management Journal, Vol. 43, No. 3, pp. 249-67.

IFMR (2011), The Base of Pyramid distribution challenge, http://cdf.ifmr.ac.in/?publication=the-base-of-pyramid-distribution-challenge (referred on $02 / 12 / 2014$ ).

Kalam, A. P. J., Singh, S. P. (2011), Target 3 Billion - PURA: Innovative Solutions Through Sustainable Development, Penguin Books, India.

Kapoor, A., Goyal, S (2013), Inclusive healthcare at base of the pyramid (BoP) in India, Int. J. Trade and Global Markets, Vol. 6, No. 1, pp. 22-39.

London, T., Hart, S. L. (2004), Reinventing Strategies for Emerging Markets: Beyond the Transnational Model, Journal of International Business Studies, Vol. 35, No. 5, pp. 350-370.

London, T., Anupindi, R., Sheth, S. (2010), Creating Mutual Value: Lessons Learned from Serving Base of the Pyramid Producers, Journal of Business Research, Vol. 63, No. 6, pp. 582-594.

Miles, M. B. (1979), Qualitative Data as an Attractive Nuisance: The Problem of Analysis, Administrative Science Quarterly, Vol. 24, No. 4, pp. 590-601.

Miles, M. B., Huberman, M. A. (1994), Qualitative Data Analysis: An Expanded Sourcebook, Sage Publications Ltd., London.

Miller, D. (1996), The Embeddedness of Corporate Strategy: Isomorphism vs. Differentiation, in Baum, J.A.C. and Dutton, J. E. (Eds.), Advances in Strategic Management, JAI Press, Greenwich, CT.

Murphy, J., Thomas, B. (2003), The Role of Business in Community Capacity Building: An Alternative Approach, http://www.communitybuilders.nsw.gov.au/487_2.html (referred on $02 / 12 / 2014)$.

Prahalad, C. K. (2004), The Fortune at the Bottom of the Pyramid: Eradicating Poverty through Profits, Upper Saddle River, NJ: Wharton School Publishing. 
Prahalad, C. K., Hammond, A. (2002), Serving the World's Poor, Profitably, Harvard Business Review, Vol. 80, No. 9, pp. 48-57.

Prahalad, C. K., Hart, S. L. (2002), The fortune at the bottom of the pyramid, Strategy + Business, Vol. 26 (First Quarter), pp. 2-14.

Putnam, R. D. (1995), Bowling Alone: America's Declining Social Capital, Journal of Democracy, Vol. 6, No. 1, pp. 65-78.

Seelos, C., Mair, J. (2005), Social Entrepreneurship: Creating New Business Models to Serve the Poor, Business Horizons, Vol. 48, No. 3, pp. 241-246.

Simanis, E., Hart, S. L. (2006), Expanding Possibilities at the Base of the Pyramid Innovations Case Discussion: KickStart, Innovations, Winter, pp. 43-51.

World Bank (2010), http://povertydata.worldbank.org/poverty/country/IND (referred on $02 / 12 / 2014)$.

World Economic Forum (2009), The Next Billions: Unleashing Business Potential in Untapped Markets, http://www3.weforum.org/docs/WEF_FB_UntappedMarkets_ Report_2009.pdf (referred on 02/12/2014).

Yin, R. K. (2009), Case Study Research: Design and Methods, $4^{\text {th }}$ ed., Sage Publications Inc., California.

Yunus, M. (2010), Building Social Business - The New Kind of Capitalism that Serves Humanity's Most Pressing Needs, Public Affairs, New York. 


\section{Appendix 1. Overview of the Social Enterprises}

\begin{tabular}{|c|c|c|c|c|}
\hline & Selco (1995) & Boond (2010) & $\begin{array}{c}\text { Narayana Hrudayalaya } \\
(2001)\end{array}$ & E Health Point (2009) \\
\hline Overview & $\begin{array}{l}\text { Managed by: Dr. H Harish } \\
\text { Hande / Mr. Neville Williams } \\
\text { Outreach: India } \\
\text { Issue Addressed: Access to } \\
\text { affordable and clean solar energy } \\
\text { solutions for the poor }\end{array}$ & $\begin{array}{l}\text { Managed by: Mr. Rustam } \\
\text { Sengupta } \\
\text { Outreach: India } \\
\text { Issue Addressed: Access to } \\
\text { affordable and clean solar } \\
\text { energy solutions for the poor }\end{array}$ & $\begin{array}{l}\text { Founded by: Dr. Devi } \\
\text { Prasad Shetty } \\
\text { Outreach: Global } \\
\text { Issue Addressed: } \\
\text { Affordable access to } \\
\text { primary, secondary and } \\
\text { tertiary care for the } \\
\text { masses. }\end{array}$ & $\begin{array}{l}\text { Managed by: Mr. Amit } \\
\text { Jain / Dr. Allen Hammond / } \\
\text { Dr. Chris Dickey } \\
\text { Outreach: India } \\
\text { Issue Addressed: Access } \\
\text { to preventive \& curative } \\
\text { primary healthcare in rural } \\
\text { and peri-urban locations. }\end{array}$ \\
\hline $\begin{array}{l}\text { Entity } \\
\text { Setup }\end{array}$ & $\begin{array}{l}\text { Hybrid (For Profit \& } \\
\text { Foundation) }\end{array}$ & $\begin{array}{l}\text { Hybrid (For Profit \& } \\
\text { Foundation) }\end{array}$ & $\begin{array}{l}\text { Hybrid (For Profit \& } \\
\text { Foundation) }\end{array}$ & $\begin{array}{l}\text { Hybrid (For Profit \& } \\
\text { Foundation) }\end{array}$ \\
\hline $\begin{array}{l}\text { Business } \\
\text { Model }\end{array}$ & Hub-N-Spoke & Hub-N-Spoke & $\begin{array}{l}\text { Asset-Light-No-Frills } \\
\text { based Cluster and Hub-N- } \\
\text { Spoke }\end{array}$ & $\begin{array}{l}\text { Asset-Light-No-Frills } \\
\text { based Cluster and Hub-N- } \\
\text { Spoke }\end{array}$ \\
\hline Mission & $\begin{array}{l}\text { To enhance the quality of life of } \\
\text { underserved households and } \\
\text { livelihoods through sustainable } \\
\text { energy solutions and services }\end{array}$ & $\begin{array}{l}\text { To bring energy access to the } \\
\text { geographically and } \\
\text { economically marginalized } \\
\text { communities in India through } \\
\text { innovative products, creative } \\
\text { financing and strong } \\
\text { servicing ecosystem }\end{array}$ & $\begin{array}{l}\text { A dream to making quality } \\
\text { healthcare accessible to the } \\
\text { masses worldwide }\end{array}$ & $\begin{array}{l}\text { To provide high quality, } \\
\text { affordable, health and safe } \\
\text { drinking water services in } \\
\text { under-served communities } \\
\text { by building and operating } \\
\text { the necessary infrastructure }\end{array}$ \\
\hline $\begin{array}{l}\text { BoP } \\
\text { Inclusion }\end{array}$ & $\begin{array}{l}\text { Consumers, Employees, } \\
\text { Entrepreneurs }\end{array}$ & $\begin{array}{l}\text { Consumers, Employees, } \\
\text { Entrepreneurs }\end{array}$ & $\begin{array}{l}\text { Consumers, Employees } \\
\text { (Paramedics) }\end{array}$ & $\begin{array}{l}\text { Consumers, Employees } \\
\text { (water-point operators and } \\
\text { nurses, outreach workers) }\end{array}$ \\
\hline Awards & $\begin{array}{l}\text { Magsaysay (2011); FT (2009); } \\
\text { Social Entrepreneur (2007); } \\
\text { Ashden Awards }(2005,2007)\end{array}$ & & $\begin{array}{l}\text { F\&S (2012), FICCI } \\
\text { (2012), CNBC (2010), The } \\
\text { Economist (2011), E\&Y } \\
\text { (2003 }\end{array}$ & $\begin{array}{l}\text { Ashoka (2011), } \\
\text { NASSCOM (2012), Tech } \\
\text { (2011), USAID (2011), } \\
\text { Sankalp (2011) }\end{array}$ \\
\hline & Selco (1995) & Boond (2010) & $\begin{array}{c}\text { Narayana Hrudayalaya } \\
\text { (2001) }\end{array}$ & E Health Point (2009) \\
\hline Partners & $\begin{array}{l}\text { Funding - Social Investors \& } \\
\text { Grants, Government (Policy), } \\
\text { Suppliers (Panels, batteries etc.), } \\
\text { Financing (SEWA, Cooperatives } \\
\text { and Regional Rural Banks, } \\
\text { MFIs), Training (RUDSETIs, } \\
\text { ITIs), Technology and Academic } \\
\text { partners. }\end{array}$ & $\begin{array}{l}\text { Funding - CIIE, IIMA, } \\
\text { Government Bodies (MNRE } \\
\text { etc for Policy), Suppliers } \\
\text { (Panels, batteries etc.), } \\
\text { Financing (Regional Rural } \\
\text { Banks, MFIs), Training } \\
\text { (Barefoot). }\end{array}$ & $\begin{array}{l}\text { Funding - Private } \\
\text { Investors \& Grants, } \\
\text { Government (Policy, } \\
\text { Technology, Insurance, } \\
\text { Network), Technology and } \\
\text { Academic partners } \\
\text { (Digital), Suppliers }\end{array}$ & $\begin{array}{l}\text { Funding - Angel Investors } \\
\text {, Government (Public- } \\
\text { Private setups), } \\
\text { Technology companies, } \\
\text { Pharmacy Chains, Local } \\
\text { Practitioners, Government } \\
\text { health centers, Suppliers }\end{array}$ \\
\hline $\begin{array}{l}\text { Outreach } \\
\text { \& Impact }\end{array}$ & $\begin{array}{l}\text { Outreach [Till 2012] } \\
\checkmark \text { Network: } 30+\text { Energy Service } \\
\text { Centers, } 8+\text { Regional offices, } \\
\text { 200+ employees } \\
\text { Social Impact[Till 2012] } \\
\checkmark 110,000+\text { households } \\
\checkmark 4000+\text { Institutions }\end{array}$ & $\begin{array}{l}\text { Outreach [Till 2012] } \\
\checkmark \text { Network: } 5 \text { Rural Energy } \\
\text { Centers (By Mar 2013) } \\
\text { Social Impact[Till 2012] } \\
\checkmark 6000+\text { households }\end{array}$ & $\begin{array}{l}\text { Outreach [Till 2011] } \\
\checkmark \text { Network: } 17+\text { hospitals, } \\
6000+\text { beds, Tele network, } \\
35 \text { heart surgeries/day, } \\
\text { 24+ Operation theatres } \\
\text { Social Impact [Till 2008] } \\
\checkmark 35000+\text { surgeries, } \\
\checkmark \text { Tele-Medicine (30000+ } \\
\text { consultations) } \\
\checkmark \text { Micro-Insurance }(1.8 \\
\text { million farmers by } 2006) \\
\checkmark \text { Skill Building (20+ PG } \\
\text { courses for nurses \& } \\
\text { doctors }\end{array}$ & $\begin{array}{l}\text { Economic [Till 2012] } \\
\checkmark \text { Network: } 8 \text { health-points, } \\
\text { 115+ water-points. } \\
\text { Social Impact[Till 2012]: } \\
\checkmark \text { Tele-medicine }(31,000 \\
\text { consultation); } \\
\checkmark \text { Diagnostic }(17,000) ; \\
\checkmark \text { Prescriptions }(36,500) ; \\
\checkmark \text { Safe drinking water } \\
\text { (300,000 users daily). }\end{array}$ \\
\hline
\end{tabular}




\begin{tabular}{|c|c|c|c|c|}
\hline & Selco (1995) & Boond (2010) & $\begin{array}{c}\text { Narayana Hrudayalaya } \\
(2001)\end{array}$ & E Health Point (2009) \\
\hline $\begin{array}{l}\text { Key } \\
\text { Activities }\end{array}$ & $\begin{array}{l}\text { 1. Transformational } \\
\text { leadership } \\
\text { 2. Unique value proposition } \\
\text { bundling energy solutions, } \\
\text { door-step servicing and } \\
\text { financing. } \\
\text { 3. Strong delivery and } \\
\text { support network and } \\
\text { engaging the local as } \\
\text { micro-entrepreneurs and } \\
\text { customer service agents. } \\
\text { 4. Focus on continuous } \\
\text { experimentations \& } \\
\text { innovations (product, } \\
\text { business model) } \\
\text { 5. Long-term partnerships } \\
\text { with like-minded suppliers } \\
\text { and equity investors. } \\
\text { 6. Strong relationships with } \\
\text { rural banks for financing } \\
\text { the poor. } \\
\text { 7. Ensuring direct presence in } \\
\text { rural and semi-urban areas } \\
\text { via brick-n-mortar setup } \\
\text { and local engagement } \\
\text { 8. Focus on s-curve growth } \\
\text { model using hub-n-spoke } \\
\text { setup }\end{array}$ & $\begin{array}{l}\text { 1. Unique value } \\
\text { proposition bundling } \\
\text { energy solutions, } \\
\text { door-step servicing } \\
\text { and financing. } \\
\text { 2. Strong network of } \\
\text { suppliers, training } \\
\text { set-ups and financing } \\
\text { partners. } \\
\text { 3. Focus on minimal } \\
\text { CAPEX investment } \\
\text { and Non-Investor } \\
\text { route in early years. } \\
\text { 4. Ensuring direct } \\
\text { presence in rural and } \\
\text { semi-urban areas via } \\
\text { brick-n-mortar setup } \\
\text { and local } \\
\text { engagement } \\
\text { 5. Technology platform } \\
\text { for crowd-funding to } \\
\text { offer energy } \\
\text { solutions to the } \\
\text { extreme poor. } \\
\text { F. Focus on s-curve } \\
\text { growth model using } \\
\text { hub-n-spoke setup }\end{array}$ & $\begin{array}{l}\text { 1. Transformational } \\
\text { leadership } \\
\text { 2. Unique value proposition } \\
\text { bundling primary, } \\
\text { secondary and tertiary care } \\
\text { with diagnostics and } \\
\text { medicines. } \\
\text { 3. Focus on Continuous } \\
\text { experimentations \& } \\
\text { innovations (process, cost) } \\
\text { 4. Strong partnerships with } \\
\text { government, investors, } \\
\text { technology and academics. } \\
\text { 5. Competency in process } \\
\text { reengineering \& cost } \\
\text { efficiency } \\
\text { 6. Telemedicine setup for } \\
\text { last-mile reach in remote } \\
\text { locations } \\
\text { 7raining and engaging the } \\
\text { BoPsegment as nurses and } \\
\text { para-medics } \\
\text { F. Focus on rapid expansion } \\
\text { by offerings and locations } \\
\text { using a combination of } \\
\text { cluster and hub-n-spoke } \\
\text { model }\end{array}$ & $\begin{array}{l}\text { 1. Transformational } \\
\text { leadership } \\
\text { 2. Unique value proposition } \\
\text { bundling preventive and } \\
\text { curative primary care with } \\
\text { diagnostics and medicines. } \\
\text { 3. Focus on Continuous } \\
\text { experimentations \& } \\
\text { innovations (offerings, } \\
\text { process, cost) } \\
\text { 4. Strong partnerships with } \\
\text { government, investors, } \\
\text { technology and academics. } \\
\text { 5. Telemedicine setup for last- } \\
\text { mile reach in remote } \\
\text { locations } \\
\text { 6. Training and engaging the } \\
\text { BoP segment as nurses, } \\
\text { water operators and para- } \\
\text { medics } \\
\text { Focus on rapid expansion } \\
\text { by offerings and locations } \\
\text { using a combination of } \\
\text { cluster and hub-n-spoke } \\
\text { model }\end{array}$ \\
\hline
\end{tabular}

Source: Created by the authors based upon the data collected from the interviews and websites of the companies. 